\title{
Concept, Issues and Challenges for Effective Facilitations in History Education
}

\author{
Akhimullah Abd Hamid ${ }^{1}$, Abdul Razaq Ahmad² \& Mohd Mahzan Awang ${ }^{3}$ \\ ${ }^{123}$ Faculty of Education UKM, MALAYSIA \\ E-mail: akhimullah1989@gmail.com
}

\begin{abstract}
This concept paper discusses the concepts of effective Education and Learning History Education. Most of the common people attribute the effectiveness of History Education to mere academic achievement. Whereas in History Education, it is not just about the knowledge of History, but also the values of History including empathy and patriotism. The improvement in the quality of learning and facilitation in particular for History Education subjects which is often considered boring and only involves memorization of facts is a false statement. History Education is far more important in applying common values that are understood and shared by all. The presentation of facts and the application of values to each historical event must be balanced and moving in parallel. Academic excellence may be easy to achieve, but the practice and appreciation of History values are paramount and are not easy to integrate into learning and facilitating. In addition, this concept paper also addresses the emerging issues and challenges faced by teachers and students in creating effective teaching and learning to achieve that goal. Emphasis will also be placed on explaining effective teaching theory as well as aspects of teacher readiness through the dimensions of content knowledge, pedagogical skills and teacher attitudes in the incorporation of Historical values. In addition, this concept paper also introduces elements of 21 st-century teaching and learning covering the areas of communication, collaboration, creativity and critical thinking. Also noteworthy are the proposed improvements to the history teacher's effective teaching practice.
\end{abstract}

Keywords: History Education, Effective Learning, Issues and Challenges of History Education, PAK-21

\section{Introduction}

Every country in the world has a good education system in the mold of the identity of their nation. However, the education system is often through a phase change when the review and evaluation carried out periodically. It is very important to ensure the sustainability and relevance of the education system practiced in any state. Arguably the countries in the world use container to form a nationeducation through core and elective subjects from the beginning of schooling. History education is a subject that has received much attention at the ministerial level in Malaysia. Its importance is proven by its appointment as a compulsory requirement to pass the Sijil Pelajaran Malaysia (SPM) in 2013. The history curriculum that has been developed by the Ministry of Education has integrated 
knowledge, skills, elements of citizenship and civic values in their implementation.

Now through the Malaysian Education Blueprint (PPPM), the ministry aims to produce students who can be equipped with up to date knowledge, skills and practice of moral values and the implementation of a sense of identity as a Malaysian citizen. (Ministry of Education Malaysia, 2013). History Education was introduced in primary schools in 2014 in all primary schools in Malaysia. Various efforts have been undertaken by the Ministry of Education through the provision of a History teacher training system, internal courses and so on. This is in line with the Malaysian Education Blueprint (PPPM) 2013-2025 which emphasizes the Higher Order Thinking Skills (HOTS) that is integrated into all subjects at school. The changes that have occurred, particularly in History Education conclude that it had enacted a comprehensive curriculum that involves design, organizational change content, pedagogical skills, time management and assessment methods that have been upgraded to measure student proficiency levels.

\section{Concept of History Education and Learning for the 21st Century}

In recent days, the 21 st century learning or PAK 21 is a serious concern for the Ministry of Education (MOE). The effectiveness of the History syllabus is dependent on the design and quality that belongs to the History teacher. Now the implementation of the Second Wave Education Quality Standards Malaysia or SKPMg2 focuses on the quality of teachers and schools. 'Standard 4' in SKPMg2 is formulated specifically to determine the quality of learning and facilitation of teachers in the classroom. Whether we realize it or not, a good history teacher shall be capable of indicating the ability and the strength of the personal qualities and professional practice and good socialization. (Anuar Ahmad, Siti Haishah Abd Rahman \& Nur Atiqah T. Abdullah. 2009). History Thinking Skills (KPS) is an element that is not foreign to the history of education in Malaysia. This is because the History education does not merely involve learning both inside and outside the classroom that are stagnant as History itself is 'alive' and have a belief system and a common understanding throughout society of Malaysia. The focus should be given not only in words but must be in explosion of facts in appreciation of historical values that are also a priority. Even so, learning history must include the nature of History thinking elements, namely the creation of situations that require critical thinking, as well as the ability to make connections between the events with one event to another.

In addition, the students are also tested in their ability in making interpretations, search data, make predictions and judgments and imaginative abilities (Zahara Aziz \& Nik Azleena Nik Ismail, 2007). Learning and facilitation such as this are able to attract students in addition to raising pupils to think and study as an expert historians. Students must master and understand the qualities of History in order to improve their way of thinking to be more critical and analytical. These skills do not come naturally, as it must be nurtured and developed in students through a diversity of skills that are applied such as chronology, data exploration, interpretation, creation and rationalizing imagination. Now, 21st Century Learning and Higher Order Thinking Skills (HOTS) are viewed as very closely linked and inseparable. Therefore the emphasis in the teaching of the 21 st century should be the main focus in developing thinking skills of students. Not only that, in line with the need to confront global market pressures, key skills students must master such as resolution of problems, reasoning, creative and innovative thinking, and so on. Changes in assessments equally applies to a percentage of questions of higher-order thinking for the nation's major examinations, namely UPSR (80\%), PT3 (80\%), SPM core (75\%) and SPM elective (50\%) from 2016 (Malaysian Examination Board. 2013).

Review of previous studies such as Siti Rohah (1998) and Mohamad Sultan (2000) can foster a sense of interest to many other researchers to measure the extent to which the smooth implementation of the history curriculum and pedagogical application patterns into practice for most history teachers in Malaysia. History education play a very important role in creating the state of the nation and realizing that Malaysia wants a society that is comprehensive, balanced and harmonious in terms of physical, emotional, spiritual and intellectual as well as the latest social that is viewed as aspects that are equally important to the identity others. In addition, the values of material and spiritual values and humanity are equally blended in the nation's patriotic clause. Now, the 4.0 industrial revolution are pressing us in the face of modernization of our current world.

With the rapid advancement of information technology, whether we like it or not, our education system are equally affected. Without realizing it, the History subject has become one of the subjects that are very important, especially for students who seats the Malaysian Certificate of Education (SPM) as it is one of the compulsory-to-pass subject in addition to Bahasa Melayu and English. Many of the teachers have misconceptions that the PAK - 21 requires advanced technology equipment, computer labs, smart classrooms and educational facilities based on other technologies to ensure the success of teaching and learning. But that is not what PAK - 21 is about. Privileges PAK - 21 focuses on four key aspects of communication, collaboration, creativity and critical thinking or dubbed as $4 \mathrm{C}$. Through the 
introduction these four aspects hopefully teaching and learning in the classroom will not be bleak and draw the active involvement of students in every teaching. Teachers who act as facilitators only need to monitor, and guide at certain times if necessary. This will make the class more interesting and not boring, especially when teaching history.

In aspects of History education, the element of communication is very important in learning. Through which students will be able to properly and ethically contribute ideas and to communicate in a personal view based on an event. The role of the teacher is that of a facilitator that provides enough questions and guide students to provide brainstorming opinion correctly. Students can be trained to speak confidently in public with a presentation of their findings. The elements of collaboration, conducted in collaboration activities can create understanding within the group through close cooperation between members. The student minds will be stimulated through the assignment of teachers. Besides, students will become more responsible and able to shape the character of a good leader. Elements of creativity is also very important. With the challenge of the Industrial Revolution 4.0, good possessing creative skills indirectly creates healthy competition among students. The last element is critical thinking. Students will gradually form a rational attitude towards a matter or situation. They can make a reasonable assessment of the positive and negative point of view. They will also slowly be guided to criticize and accept criticism and views of other students. This is where the HOTS play an important role in encouraging students to think in a more rational and fair attitude in addition to the practice of value by the students. Osman Muamat (2016) says that teachers in the classroom should have a background in education and has been trained in the subjects they teach. Thus it can be made more effective teaching and facilitation.

\section{Effective Teaching of History Education}

Many theories and teaching models were developed to give guidance on effective teaching model such as in Slavin (1994). Slavin's model shows that the effectiveness of a teacher is affected by several factors such as the quality of teaching practice, teaching conformance level, the incentives given and a lesson in progress. However, this model is also a guide and modified according to the needs of today's lessons. Many effective teaching researchers conducted a study to divide three main components that are the attitudes of teachers, teaching aspects of content knowledge and pedagogical skills all of which are closely associated with this Slavin model. Teaching and facilitation in a session will not achieve all objectives if teachers do not master these three things. One of the effective teaching techniques used by history teachers is the use of thinking maps or i-THINK. It is very popular among teachers as it helps to facilitate the understanding of the students in terms of timelines and events in history.

Besides that, the thinking maps also help clarifies qualities as well as show relationships between events. The research studied by Salleh S.S \& Ismail R. (2013), Mohd Mahzan Awang, Abdul Razaq Ahmad \& Mohd Muhaimi Abdul Rahman (2014), and Mazlan Husin, Mohd Mahzan Awang \& Anuar Ahmad (2017) showed the effectiveness of using mind maps for History education. Apart from that, learning and facilitation aided by information and communication technology (ICT) is one of the effective methods of teaching that are often used by teachers today. According to Norakma Mohd Daud, Abdul Razaq Ahmad and Noria Munirah Yakub (2015) learning is based on higher order thinking skills (HOTS) in the teaching and learning of history shows that HOTS can serve as a platform to attract students learn history and make it a subject of interest.

The use of appropriate materials and models can also help to improve the effectiveness of HOTS in the classroom. This proves that teachers are free to use the method that is appropriate based on the ability of their pupils. The most important matter is the end result of achieving the objectives set. This statement is supported by the study conducted by Siti Aishah Mohd Firdaus and Mohd Mahzan Awang (2017) on the use of technology in teaching and learning history of the 21 st century. The findings show that the construction of the module framework guided by the teaching of history ASSURE Model aided by ICT gives a positive impact on the subjects of history in this century -21 . Construction of module like this is very important and helpful to the History teacher to diversify the teaching methods used to effectively replace the traditional teaching methods. The diversity of pedagogical skills of teachers as the best teaching practices vary - depending on the passage of time and the level of student ability. However, the priority that remains is that the result of productivity will harvest the best results and develop comprehensive intellectual human beings.

\section{Issues and Challenges in Education History}

\subsection{Quality Learning and facilitation in History Education}

In an effort to create an atmosphere that is conducive to learning and teaching that effective and meaningful, then this is where teachers are challenged to use all his skills guided by the theories learned. Each teacher has their own signature pattern and practice of effective teaching lessons. Differences 
in background and existing knowledge of students greatly influence the methods and techniques of teaching. There are many issues that are often discussed on the subject of History Education ranging from the curriculum development History, History curriculum content, pedagogical expertise in History, the facts presented and the like.

History education is also seen by some individuals, teachers and students as subjects that are not important to learn. The needs to memorize event and to know civilizations, have lead to students thinking that the History subject is merely about memorizing, thus reducing their interest to learn. Uniquely in the Malaysian context, our education system has set new requirements to pass the Sijil Pelajaran Malaysia (SPM) on the subject of History education in addition to Bahasa Melayu and English. This situation has indirectly raised the dignity of History education as one of the main subjects in Malaysia. History education should not be seen merely as subjects to be mastered to meet the requirements to pass the examination, but should instead be seen as appreciations of the value of the historic events that have occurred.

\subsection{Lack of Teachers Education in History Specialization}

Teachers need to improve the quality of History teaching in particular subjects that are considered boring and involve memorization of facts alone. The findings of a study conducted by Mazlan Husin, Mohd Mahzan Awang and Anuar Ahmad (2017) show that there is a difference in terms of the willingness of teachers specialization and teachers are not majoring in history. In addition, the analysis of the findings also show that there is a difference in terms of skills, attitudes and consumption levels of thinking maps between experienced teachers with inexperienced teachers. When we assess the ability of experienced teachers with less experienced teachers, the often arising assumption is that less experienced teachers are not competent in teaching. However, in a study conducted by Fazida Ahmad and Nurfaradilla Nasri (2018) shows that teachers who are experienced and inexperienced are competent in knowledge and be able to perform learning of the 21 st century with similarly high mean. This indicates that less experienced teachers are also able to stand tall alongside experienced teachers in terms of knowledge.

Issues regarding teachers, teaching options are also never ending, and studies have showed that teachers are made to teach subjects they don't specialize in. The issues of the lack of History optionists from IPG to meet the needs of history teachers in primary schools in Malaysia are still talked about today. This is due to the first release of History
- specialized teacher in 2017 have not been able to accommodate the number of vacancies of History teachers. Worse yet, History is considered as an elective subject and not as important as other core subjects as it is not include in subjects UPSR, so much so its periods are replaced with other core subjects. This is serious concern as primary school History is the foundation of secondary school History.

\subsection{Nurturing and Practice of History Values}

According to Zunaida Zakaria, Abdul Razak Ahmad and Mohd. Mahzan Awang (2016) stated that the subject of History education is instrumental in the perspective of patriotism. This subject is viewed as relevant to fostering healthy social well established societal values that are balanced and harmonious. History Education can also shape the characters of the students who are able to embrace the principles of Rukun Negara and strengthen national identity in them. However, according to Abdullah et. all (2015) says that students in Malaysia have the knowledge but they are not able to apply the knowledge in the subjects studied.

This is the big challenge for teachers of History because the output of students depends not only on academic performance but also involves the application and practice of the history in their life. Through appreciation, we can build and foster the spirit of patriotism, love of country on earth this independence. However, questions are frequently asked about the extent to which an individual practices the values learned in History in their everyday lives. In addition, the Education History is also viewed as having little commercial value in some countries as it is considered that there is no urgent need for the country to have experts in the field of History.

\section{Proposed Improvements in Effective Teaching Practices in History Education}

Looking at the issues that were discussed, there are some suggestions for improvement of effective teaching practices, among which includes the teachers playing their role in attending various pedagogical course to suit students needs. Prioritization of PAK -21 is not based on technology but rather to meet the needs of students to develop their basic skills thoroughly. In addition, the teachers of History should also be smart to build academic networks through partnerships with schools and other History teachers, and make masterful History teachers as their references. Internally, the school can take the initiative to hold a PLC among History teachers in schools to improve the quality of their teaching. In addition, teachers of different options should be prepared to teach History with knowledgeable 
History content, pedagogical skills and have a positive attitude to continue to foster the values of history in students.

To meet the needs of History optionist education, the Ministry of Education and higher education must cooperate to open more courses of study for History Education to meet the gaps that exist. With this, the shortage of History Education optionist teachers can be quickly resolved. To meet the aspirations of the countries with the application of historical value such as empathy and patriotism. Certainly there is no appropriate benchmark to assess the level of appreciation of the value. However, appreciation of this history can be expressed through behavior and daily practice of students. Teachers need to be smart and play a role by encouraging and a good example in fostering the love for the homeland to all students, without prejudice to any race. Practicing historical values through good behavior will eventually make a significant contribution to the country.

\section{Conclusion}

Teaching practices are strongly associated with student achievement, but the specialization of the teacher was not the reason for the weakness in a learning and facilitation. What is important is the attitude of a teacher who does not give up and constantly improve on their weaknesses. Being critical and creative should be a major trigger for improving the quality of teaching in the classroom. Students should be educated properly in order to become national leaders in the future to better cover all areas. Academic excellence of students also must keep pace with the appreciation of the History values for our nation-civilization to be preserved and passed on from one generation to the next.

\section{References}

[1] Abdullah, A.H., Aris, B., Saud, M.S., Boon, Y. , \& Awang Ali, S.A. 2015. Pelaksanaan Kemahiran Berfikir Aras Tinggi (KBAT): Isu dan Cabaran dalam Aspek Kurikulum, Pedagogi dan Pentaksiran. Seminar Kebangsaan Majlis Dekan-Dekan Pendidikan Universiti Awam 2015, 14-15 September 2015, p. 77-88.

[2] Anuar Ahmad, Siti Haishah Abd Rahman \& Nur Atiqah T. Abdullah. 2009. Tahap Keupayaan Pengajaran Guru Sejarah dan Hubungannya dengan Pencapaian Murid di Sekolah Berprestasi Rendah. Jurnal Pendidikan Malaysia 34 (1): 53-66

[3] Fazida Ahmad \& Nurfaradilla Nasri. 2018. Tahap Kompetensi Pengetahuan Guru Sejarah dalam Melaksanakan Kaedah Pengjaran dan Pembelajaran Abad ke-21. International Conference on Global Education VI Vol $1: 338-346$
[4] Kementerian Pendidikan Malaysia. 2013. Pelan Pembangunan Pendidikan Malaysia 2013 - 2025 (Pendidikan Prasekolah hingga Lepas Menengah). Putrajaya: Malaysia.

[5] Lembaga Peperiksaan Malaysia. 2013. Elemen Kemahiran Berfikir Aras Tinggi (KBAT) Dalam Instrumen Pentaksiran. Putrajaya: Kementerian Pendidikan Malaysia

[6] Mazlan Husin, Mohd Mahzan Awang \& Anuar Ahmad. 2017. Teacher Readiness in Teaching and Learning History Process through i-Think Mind Maps. Yupa: Historical Studies Journal. Vol 1(2) : 183 - 198

[7] Mohammad Sultan Faujar. 2000. Kualiti Pengajaran Sejarah di Sekolah Menengah Daerah Sabak Bernam. Tesis Sarjana. Universiti Malaya.

[8] Mohd Mahzan Awang, Abdul Razaq Ahmad \& Mohd Muhaimi Abdul Rahman. 2014. Penggunaan Peta Minda oleh Pelajar Pintar Cerdas dalam Pembelajaran Sejarah. Jurnal Pendidikan Malaysia 39(2) : 95 - 100

[9] Norakma Mohd Daud, Abdul Razaq Ahmad \& Noria Munirah Yakub. 2015. Pembelajaran Berteraskan Kemahiran Berfikir Aras Tinggi (KBAT) di dalam Pengajaran dan Pembelajaran Mata Pelajaran Sejarah. Proceeding: 7th International Seminar on Regional Education, November 5-7 Vol $1: 352-360$

[10] Osman Muamat. 2016. Persepsi Pelajar Terhadap Amalan Pengajaran Guru Opsyen Dan Bukan Opsyen Sejarah Serta Hubungannya Dengan Sikap Pelajar. Tesis Sarjana. Fakulti Pendidikan Universiti Kebangsaan Malaysia

[11] Salleh S.S., Ismail R. 2013. Effectiveness of Concept Map Approach in Teaching History Subject. In: Zaman H.B., Robinson P., Olivier P., Shih T.K., Velastin S. (eds) Advances in Visual Informatics. IVIC. Lecture Notes in Computer Science, vol 8237. Springer, Cham : 683 - 693

[12] Siti Aisyah Mohd Firdaus \& Mohd Mahzan Awang. 2017. Penggunaan Teknologi dalam Pengajaran dan Pembelajaran Sejarah Abad ke-21. Proceeding Kuala Lumpur International Communication, Education, Language and Social Sciences 8 (KLiCELS 8), 2 - 3 December : 176 - 185

[13] Siti Rohah Abdullah. 1998. Sikap Guru Dalam Pengajaran Sejarah. Kertas Projek Sarjana. Universiti Utara Malaysia.

[14] Slavin, R. 1994. A theory of school and classroom organization. Eduational Psychologist, 22, 89-108.

[15]Zahara Aziz \& Nik Azleena Nik Ismail. 2007. Kajian Tinjauan Kesediaan Guru-guru Sejarah Menerapkan Kemahiran Pemikiran Sejarah kepada Para Pelajar. Jurnal Pendidikan 32 (1): 119-13.

[16]Zunaida Zakaria, Abdul Razak Ahmad \& Mohd. Mahzan Awang . 2016. Peranan Kurikulum Sejarah Sekolah Rendah Ke Arah Pemupukan Semangat Patriotik dalam 
Kalangan Murid Sekolah Rendah. Prosiding: Persidangan

Pemantapan Citra Kenegaraan 4, 13-15 Mac : 513 - 523 